TITLE:

\title{
Effects of amines and aminoalcohols on bovine intestine alkaline phosphatase activity
}

\section{$\operatorname{AUTHOR}(\mathrm{S})$ :}

Sekiguchi, Satoshi; Hashida, Yasuhiko; Yasukawa, Kiyoshi; Inouye, Kuniyo

\section{CITATION:}

Sekiguchi, Satoshi ... [et al]. Effects of amines and aminoalcohols on bovine intestine alkaline phosphatase activity. Enzyme and Microbial Technology 2011, 49(2): 171-176

\section{ISSUE DATE:}

2011-07

URL:

http://hdl.handle.net/2433/143675

\section{RIGHT:}

@ 2011 Elsevier Inc.; この論文は出版社版でありません。引用の際には 出版社版をご確認ご利用ください。; This is not the published version. Please cite only the published version. 
1 Enzyme and Microbial Technology

2

3 Effects of amines and aminoalcohols on bovine intestine alkaline phosphatase activity

4

5 Satoshi Sekiguchi, Yasuhiko Hashida, Kiyoshi Yasukawa, Kuniyo Inouye*

6

7 Division of Food Science and Biotechnology, Graduate School of Agriculture,

8 Kyoto University, Sakyo-ku, Kyoto 606-8502, Japan

9

10 Keywords: Alkaline phosphatase, Amine, Aminoalcohol, Bovine intestine alkaline 11 phosphatase, Enzyme immunoassay

12

13 Abbreviations: ALP, alkaline phosphatase; BIALP, bovine intestine alkaline phosphatase;

14 EIA, enzyme immunoassay; pNPP, $p$-nitrophenyl phosphate

15

16 "Corresponding author. Tel: +81-75-753-6266; Fax: +81-75-753-6265;

17 E-mail address: inouye@kais.kyoto-u.ac.jp 
19

20

21

22

\section{Abstract}

Bovine intestine alkaline phosphatase (BIALP) is widely used as a signaling enzyme in sensitive assays such as enzyme immunoassay (EIA). In this study, we evaluated the effects of various aminoalcohols and amines on the activity of BIALP in the hydrolysis of $p$-nitrophenyl phosphate (pNPP) at $\mathrm{pH} 9.8$, at $20^{\circ} \mathrm{C}$. The $k_{\text {cat }}$ values at $0.05 \mathrm{M}$ diethanolamine, 0.1 M triethanolamine, and 0.2 M N-methylethanolamine were $190 \pm 10$, $840 \pm 30$, and $500 \pm 10 \mathrm{~s}^{-1}$, respectively. The $k_{\mathrm{cat}}$ values increased with increasing concentrations of diethanolamine, triethanolamine, and $\mathrm{N}$-methylethanolamine and reached $1240 \pm 60,1450 \pm 30$, and $2250 \pm 80 \mathrm{~s}^{-1}$, respectively, at $1 \mathrm{M}$. On the other hand, the $k_{\mathrm{cat}}$ values at 0.05-1.0 $\mathrm{M}$ ethanolamine, ethylamine, methylamine, and dimethylamine were in the range of $100-600 \mathrm{~s}^{-1}$. These results indicate that diethanolamine, triethanolamine, and $\mathrm{N}$-methylethanolamine highly activate BIALP and might be suitable as a dilution buffer of BIALP in EIA. Interestingly, the $K_{\mathrm{m}}$ values increased with increasing concentrations of diethanolamine and $N$-methylethanolamine, but not triethanolamine: the $K_{\mathrm{m}}$ value at $1.0 \mathrm{M}$ diethanolamine $(0.83 \pm 0.15 \mathrm{mM})$ was 12 -fold higher than that at $0.05 \mathrm{M}(0.07 \pm 0.01 \mathrm{mM})$, and that at $1.0 \mathrm{M} \mathrm{N}$-methylethanolamine $(2.53 \pm 0.20 \mathrm{mM})$ was 14 -fold higher than that at $0.2 \mathrm{M}(0.18 \pm 0.02 \mathrm{mM})$, while that at $1.0 \mathrm{M}$ triethanolamine $(0.31 \pm 0.01 \mathrm{mM})$ was similar as that at $0.2 \mathrm{M}(0.25 \pm 0.01 \mathrm{mM})$, suggesting that the mechanisms of BIALP activation are different between the aminoalcohols. 


\section{Introduction}

Phosphatases (EC 3.1.3.1) catalyze the hydrolysis of phosphomonoesters. They are classified into two groups as alkaline phosphatase (ALP) and acid phosphatase (ACP) depending on their optimal $\mathrm{pH}$ in alkaline and acidic $\mathrm{pH}$ regions, respectively. ALPs are widely distributed in many bacteria and mammals, and play an essential role in biochemical processes [1-4]. Their structural and functional properties are considered to be commonly conserved in all ALPs. ALP is a homodimeric metalloenzyme. The subunit has a molecular mass of about $50 \mathrm{kDa}$ and contains two $\mathrm{Zn}^{2+}$ and one $\mathrm{Mg}^{2+}$ ions [5,6]. The catalytic triad composed of the two $\mathrm{Zn}^{2+}$ and one $\mathrm{Mg}^{2+}$ ions is conserved in all ALPs from Escherichia coli to mammals [7]. Mammalian ALP is present in the liver, intestine, placenta, kidney, and other tissues. The molecular activity, $k_{\mathrm{cat}}$, of mammalian ALP is $10-60$ times higher than that of E. coli ALP [8].

Bovine intestine ALP (BIALP) has the highest specific activity among mammalian ALPs. Therefore, it has been applied as a signaling enzyme in sensitive assays such as enzyme immunoassay (EIA), Western blotting analysis, nucleic acid hybridization assay, and polymerase chain reaction and has been used in diagnosis, immunology, and molecular biology [9-11]. We developed a fully automated random-accessible type EIA diagnosis system, AIA, with BIALP (Tosoh, Tokyo, Japan). In this system, 180 assays could be done in $1 \mathrm{~h}$ with the sensitivity of an attomole level using $0.1 \mathrm{ml}$ sample solution. Generally, in EIA, the concentration of the analyte is translated to the activity of the signaling enzyme. The concentration of the enzyme-reaction product is measured using signals such as absorbance, fluorescence, and luminescence. Various enzymes such as ALP, $\beta$-galactosidase, glucoamylase, and peroxidase have been used for this purpose [12]. Presently, BIALP and 
horseradish peroxidase (HRP) are the most extensively used due to high activity. According to the Michaelis-Menten equation, the reaction velocity is proportional to the concentration and $k_{\text {cat }}$ of the signaling enzyme. Therefore, the sensitivity and rapidness of EIA increase if $k_{\text {cat }}$ of the signaling enzyme increases. This means that activation of the signaling enzyme makes the EIA system more sensitive and rapid. Regarding this, we developed several technologies, and demonstrated that they were effective [13-16]. First, to reduce non-specific binding of the BIALP-labeled antibodies (Abs) to the immobilized Abs, we produced $\mathrm{F}\left(\mathrm{ab}{ }^{\prime}\right)_{2}$ fragments and used them as Abs to be immobilized, instead of intact IgG or $\operatorname{IgM}$ Abs, $[13,14]$. Secondly, considering that chemical labeling of BIALP to Ab sometimes makes BIALP and Ab inactivated, we produced bi-specific Abs that bind with antigen and BIALP simultaneously and used them as the Abs for detection, instead of covalently BIALP-labeled Abs [15,16]. Thirdly, to increase the reaction velocity, we produced dimerized and trimerized BIALPs by chemical conjugation with glutaraldehyde and labeled them to the Abs for detection, instead of monomeric BIALP [15].

Enzyme activity depends on buffer species as well as $\mathrm{pH}$. Bannister and Foster reported that tris, imidazole, phosphate ion, and bicarbonate ion increased BIALP activity [17]. Stinson reported that 2-(ethylamino)ethanol increased BIALP probably by acting as a phophoacceptor [18]. Today, diethanolamine is commonly used as a dilution buffer of BIALP $[19,20]$. However, the activation mechanism of these substances has not been well elucidated. In this study, to address this issue, we examined the effects of various amines and aminoalcohols (Fig. 1) on BIALP activity. We also discuss the importance of BIALP activation from a viewpoint of its diagnostic use.

\section{Materials and methods}




\subsection{Materials}

92

BIALP (lot 92958657) was purchased from Roche Diagnostics (Basel, Switzerland).

The preparation was used without further purification. $p$-Nitrophenyl phosphate (pNPP) (lot M4R4749) was from Nacalai Tesque (Kyoto, Japan). Its concentration was determined spectrophotometrically using the molar absorption coefficient, $\varepsilon_{310}$, of $10,380 \mathrm{M}^{-1} \mathrm{~cm}^{-1}$, which we determined in this study. All other chemicals were of reagent grade and purchased from Nacalai Tesque and Wako Pure Chemical (Osaka, Japan).

\subsection{Hydrolysis of pNPP}

The BIALP-catalyzed hydrolysis of pNPP was initiated by mixing $2,990 \mu \mathrm{l}$ of the substrate solution pre-incubated at $20^{\circ} \mathrm{C}$ and $10 \mu \mathrm{l}$ of the BIALP solution (12 nM). The substrate solutions were 0.05-3.0 $\mathrm{M}$ diethanolamine- $\mathrm{HCl}, 0.2-1.0 \mathrm{M}$ ethylamine- $\mathrm{HCl}$, 0.05-0.5 $\mathrm{M}$ ethanol containing 0.05 $\mathrm{M}$ diethanolamine- $\mathrm{HCl}, 0.05-1.0 \mathrm{M}$ methylamine- $\mathrm{HCl}$ containing $0.05 \mathrm{M}$ diethanolamine, $0.2-1.0 \mathrm{M}$ dimethylamine- $\mathrm{HCl}$ containing 0.05 diethanolamine, 0.05-1.0 M ethanolamine- $\mathrm{HCl}, 0.1-1.0 \mathrm{M}$ triethanolamine- $\mathrm{HCl}, 0.2-1.0 \mathrm{M}$ $N$-methylethanolamine- $\mathrm{HCl}$, and $0.05-0.5 \mathrm{M}$ borate- $\mathrm{NaOH}$, each containing $1.0 \mathrm{mM} \mathrm{MgCl} 2$ and $20 \mu \mathrm{M} \mathrm{ZnCl} 2$, at $\mathrm{pH}$ 9.8. The initial enzyme and substrate concentrations were $40-400$ $\mathrm{pM}$ and $0.01-15 \mathrm{mM}$, respectively. The reaction was carried out at $20^{\circ} \mathrm{C}$ and measured by following the increase in absorbance at $405 \mathrm{~nm}, A_{405}$, with a JASCO V-550 spectrophotometer (Tokyo). The product, $p$-nitrophenol, was estimated using the molar absorption difference due to the hydrolysis, $\Delta \varepsilon_{405}=17,500 \mathrm{M}^{-1} \mathrm{~cm}^{-1}$, at $20^{\circ} \mathrm{C}$, which we 
114 determined in this study. The kinetic parameters, the molecular activity $\left(k_{\text {cat }}\right)$ and Michaelis

115 constant $\left(K_{\mathrm{m}}\right)$, were calculated from Hanes-Woolf equation (Eq. 1) by 116 least-squares-regression.

117

$$
\frac{1}{v_{\mathrm{o}}}=\frac{K_{\mathrm{m}}}{V_{\max }[\mathrm{S}]_{\mathrm{o}}}+\frac{1}{V_{\max }}
$$

119 In this equation, $v_{\mathrm{o}}, V_{\max }$, and $[\mathrm{S}]_{\mathrm{o}}$ are the initial reaction rate, the maximal initial reaction 120 rate, and the initial substrate concentration, respectively. The value of $k_{\text {cat }}$ was calculated 121 from $V_{\max }$ obtained using a monomer molecular mass of $50 \mathrm{kDa}$.

\section{Results}

\subsection{Effects of diethanolamine on the BIALP-catalyzed hydrolysis of pNPP} made kinetic analysis of BIALP in the hydrolysis of pNPP with various concentrations of diethanolamine. The dependences of $v_{\mathrm{o}}$ at $\mathrm{pH} 9.8$, at $20^{\circ} \mathrm{C}$ on the substrate concentration are shown in Fig. 2. All plots showed saturated profiles, and the $k_{\text {cat }}$ and $K_{\mathrm{m}}$ values of BIALP were determined separately (Table 1 ). The $k_{\text {cat }}$ and $K_{\mathrm{m}}$ values markedly increased with increasing concentrations of diethanolamine. The $k_{\text {cat }}$ value at $3.0 \mathrm{M}$ diethanolamine was

$1332330 \pm 30 \mathrm{~s}^{-1}$, which was 12 -fold higher than that at $0.05 \mathrm{M}\left(190 \pm 10 \mathrm{~s}^{-1}\right)$, and the $K_{\mathrm{m}}$ value 
Diethanolamine has amino and hydroxyl groups. Based on the assumption that the hydroxyl group of diethanolamine is involved in the activation of BIALP, we made kinetic analysis of BIALP in the hydrolysis of pNPP with varying concentrations $(0.05-1.0 \mathrm{M})$ of ethylamine, ethanol, methylamine, and dimethylamine. To maintain $\mathrm{pH}$ of the solution at 9.8, $0.05 \mathrm{M}$ diethanolamine was contained in the solutions with methylamine, dimethylamine, and ethanol. The dependences of $v_{\mathrm{o}} /[\mathrm{E}]_{\mathrm{o}}$ on the substrate concentration in the presence of $1.0 \mathrm{M}$ diethanolamine, ethylamine, methylamine, or dimethylamine or $0.5 \mathrm{M}$ ethanol are shown in Fig. 3. The $v_{0} /[\mathrm{E}]_{\mathrm{o}}$ values with ethylamine, methylamine, dimethylamine, and ethanol were considerably lower than those with diethanolamine at all substrate concentrations examined. Because all plots showed saturated profiles, the $k_{\text {cat }}$ and $K_{\mathrm{m}}$ values were determined separately (Table 2). The $k_{\text {cat }}$ values were stable with increasing concentrations of ethylamine: the value at $1.0 \mathrm{M}$ ethylamine was $400 \pm 30 \mathrm{~s}^{-1}$, which was $90 \%$ of that at $0.2 \mathrm{M}\left(450 \pm 10 \mathrm{~s}^{-1}\right)$. The $k_{\text {cat }}$ values decreased with increasing concentrations of ethanol: the value at $0.5 \mathrm{M}$ ethanol was $100 \pm 10 \mathrm{~s}^{-1}$, which was $50 \%$ of that at $0.05 \mathrm{M}$ $\left(200 \pm 20 \mathrm{~s}^{-1}\right)$. The $k_{\text {cat }}$ values increased with increasing concentrations of methylamine and dimethylamine: the value at $1.0 \mathrm{M}$ methylamine was $330 \pm 30 \mathrm{~s}^{-1}$, which was $240 \%$ of that at $0.05 \mathrm{M}\left(140 \pm 20 \mathrm{~s}^{-1}\right)$, and that at $1.0 \mathrm{M}$ dimethylamine was $370 \pm 10 \mathrm{~s}^{-1}$, which was $250 \%$ of that at $0.2 \mathrm{M}\left(150 \pm 10 \mathrm{~s}^{-1}\right)$. These results indicate that ethylamine and ethanol do not activate and methylamine and dimethylamine activate BIALP. However, the magnitudes

159 of the activation by methylamine and dimethylamine were not remarkable compared to that by diethanolamine. 
To see whether aminoalcohols other than diethanolamine activate BIALP, we made

kinetic analysis of BIALP in the hydrolysis of pNPP with varying concentrations (0.05-1.0 M) of ethanolamine, triethanolamine, and $N$-methylethanolamine. Borate was also used as a negative control. The dependences of $v_{\mathrm{o}} /[\mathrm{E}]_{\mathrm{o}}$ on the substrate concentration at $1.0 \mathrm{M}$ diethanolamine, ethanolamine, triethanolamine, and $N$-methylethanolamine and $0.5 \mathrm{M}$ borate are shown in Fig. 4. The $v_{\mathrm{o}} /[\mathrm{E}]_{\mathrm{o}}$ values with $N$-methylethanolamine were the highest for $0.4-1.0 \mathrm{mM} \mathrm{pNPP}$ and that with triethanolamine was the highest for $0.2 \mathrm{mM} \mathrm{pNPP}$. Because all plots showed saturated profiles, the $k_{\text {cat }}$ and $K_{\mathrm{m}}$ values were determined separately (Table 3). The $k_{\text {cat }}$ values increased with increasing concentrations of triethanolamine and $N$-methylethanolamine: the value at $1.0 \mathrm{M}$ triethanolamine was $1450 \pm$ $30 \mathrm{~s}^{-1}$, which was $180 \%$ of that at $0.1 \mathrm{M}\left(840 \pm 30 \mathrm{~s}^{-1}\right)$, and the value at $1.0 \mathrm{M}$ $N$-methylethanolamine was $2250 \pm 80 \mathrm{~s}^{-1}$, which was $450 \%$ of that at $0.2 \mathrm{M}\left(500 \pm 10 \mathrm{~s}^{-1}\right)$. The $k_{\text {cat }}$ values decreased with increasing concentrations of ethanolamine: the value at $1.0 \mathrm{M}$ ethanolamine was $300 \pm 10 \mathrm{~s}^{-1}$, which was $50 \%$ of that at $0.05 \mathrm{M}\left(610 \pm 200 \mathrm{~s}^{-1}\right)$. The $k_{\text {cat }}$ values were stable with increasing concentrations of borate: the value at $0.5 \mathrm{M}$ borate was $120 \pm 10 \mathrm{~s}^{-1}$, which was $90 \%$ of that at $0.05 \mathrm{M}\left(130 \pm 10 \mathrm{~s}^{-1}\right)$. These results indicate that ethanolamine does not activate and triethanolamine and $N$-methylethanolamine activate BIALP.

The $K_{\mathrm{m}}$ values were stable with increasing concentrations of ethanolamine: the value at 1.0 $\mathrm{M}$ ethanolamine was $0.30 \pm 0.01 \mathrm{mM}$, which was identical to that at $0.05 \mathrm{M}(0.30 \pm 0.02$ $\mathrm{mM})$. The $K_{\mathrm{m}}$ values slightly increased with increasing concentrations of triethanolamine: 
the value at $1.0 \mathrm{M}$ triethanolamine was $0.31 \pm 0.01 \mathrm{mM}$, which was $130 \%$ of that at $0.1 \mathrm{M}$ $(0.24 \pm 0.03 \mathrm{mM})$. The $K_{\mathrm{m}}$ values markedly increased with increasing concentrations of $N$-methylethanolamine and borate: the value at $1.0 \mathrm{M} N$-methylethanolamine was $2.53 \pm$ $0.20 \mathrm{mM}$, which was $1400 \%$ of that at $0.2 \mathrm{M}(0.18 \pm 0.02 \mathrm{mM})$, and the value at $0.5 \mathrm{M}$ borate was $10.30 \pm 0.41 \mathrm{mM}$, which was $2100 \%$ of that at $0.05 \mathrm{M}(0.49 \pm 0.02 \mathrm{mM})$. Consequently, the $k_{\mathrm{cat}} / K_{\mathrm{m}}$ values increased with increasing concentrations of triethanolamine, and decreased with increasing concentrations of ethanolamine, $N$-methylethanolamine, and borate.

\section{Discussion}

\subsection{Effects of amines on BIALP activity}

In this study, we determined the $k_{\text {cat }}$ and $K_{\mathrm{m}}$ values of BIALP in the hydrolysis of pNPP with varying concentrations of three amines, methylamine, dimethylamine, and ethylamine, one alcohol, ethanol, and four aminoalcohols, ethanolamine, diethanolamine, triethanolamine, and $\mathrm{N}$-methylethanolamine (Fig. 1). We demonstrate that diethanolamine, triethanolamine, and $N$-methylethanolamine activate BIALP.

The $k_{\text {cat }}$ values increased with increasing concentrations of methylamine and dimethylamine, and were stable with increasing concentrations of ethylamine (Table 2). The magnitudes of the activation by methylamine and dimethylamine are not remarkable compared to that by diethanolamine (Table 1). This suggests that methyl group has activating effects on BIALP although the precise mechanism is not known. Recently, Yang et al. reported the effects of high concentrations (about $1 \mathrm{M}$ ) of neutral salts on calf intestine 
209 ALP activity [21]. They showed that the activating and stabilizing effects of neutral salts correlated with the Hofmeister series. The effects of neutral salts on BIALP are the next subject. In regard to this, we reported that neutral salts remarkably activated thermolysin, a

212 thermostable neutral metalloproteinase produced in the culture broth of Bacillus

213 thermoproteolyticus [22]. Importantly, the orders of ions for the efficiency in the activation

214 and the increase in the solubility of thermolysin were $\mathrm{Na}^{+}>\mathrm{K}^{+}>\mathrm{Li}^{+}$, which was different from Hofmeister's series corresponding to the degree of hydration of ions: $\mathrm{Li}^{+}>\mathrm{Na}^{+}>\mathrm{K}^{+}$ [22-24].

\subsection{Effects of aminoalcohols on BIALP activity}

The $k_{\text {cat }}$ values of BIALP in the hydrolysis of pNPP increased with increasing concentrations of diethanolamine, triethanolamine, and $\mathrm{N}$-methylethanolamine, indicating that they activate BIALP and might be suitable as a dilution buffer of BIALP in EIA. In contrast, The $K_{\mathrm{m}}$ values increased with increasing concentrations of diethanolamine and $N$-methylethanolamine, but not triethanolamine, suggesting that the mechanisms of BIALP activation are different between the aminoalcohols.

The active site of ALP has two $\mathrm{Zn}^{2+}$ ions and one $\mathrm{Mg}^{2+}$ ion. According to X-ray structural study of $E$. coli ALP [5,6,25], the catalytic mechanism of ALP has been thought as follows: in free enzyme, the hydroxyl group of active-site Ser residue coordinates one $\mathrm{Zn}^{2+}$ ion $(\mathrm{Zn} 2)$. The Michaelis complex is formed when the ester oxygen atom of the substrate coordinates another $\mathrm{Zn}^{2+}$ ion $(\mathrm{Zn} 1)$ and the non-bridging oxygen atom of the substrate coordinates $\mathrm{Zn} 1$. Zn2 polarizes the hydroxyl group the Ser. Ionized Mg-bound water molecule accepts a proton from the Ser. The covalent enzyme-phosphate intermediate 
is formed when the ionized hydroxyl group of the Ser attacks the phosphorus atom. Then, the first product is released. Ionized $\mathrm{Zn1-bound} \mathrm{water} \mathrm{molecule} \mathrm{attacks} \mathrm{the} \mathrm{phosphorus} \mathrm{atom.}$ The Mg-bound water molecule now gives a proton to the Ser. Finally, the phosphate group is released.

There are two possible mechanisms for the activation of BIALP by aminoalcohols [17-20]. One is that aminoalcohols are located at the active site of BIALP and receive the leaving phosphate group more efficiently than water molecule. The aminoalcohols-phosphate complex is hydrolyzed when the complex releases from the enzyme. Another possibility is that aminoalcohols bind BIALP out of the active site and activate it. In both cases, the initial reaction rate could be saturated as the aminoalcohol concentration increases. To address this issue, $v_{\mathrm{o}}$ of BIALP in the hydrolysis of pNPP was plotted against aminoalcohol concentrations for each pNPP concentration (Fig. 5). The reaction with diethanolamine exhibited Michaelis-Menten profiles (Fig. 5A). The $K_{\text {m,diethanolamine }}$ values at the pNPP concentrations of $0.2,0.4,0.6,0.8,1.0,2.0,3.0,4.0$, and $5.0 \mathrm{mM}$ were $64 \pm 23,160 \pm 60,260 \pm 50,360 \pm 80,400 \pm 100,820 \pm 170,1000 \pm 200$ $1300 \pm 300$, and $1300 \pm 300 \mathrm{mM}$, respectively, indicating the value increased with increasing concentrations of pNPP. On the other hand, the reaction with triethanolamine and $N$-methylethanolamine exhibited the saturation curve, but did not exhibit Michaelis-Menten profiles (Figs. 5B and C). Our results suggest that the mechanisms of BIALP activation are different between the aminoalcohols although the difference cannot be precisely explained at this stage. 
In the application of ALP to EIA, some substrates are used depending on the principle of

258

259

260

261

262

263

264

265

the product-detection system. Namely, with the pNPP substrate, the product $p$-nitrophenol (pNP) gives a strong yellow color at neutral and alkaline $\mathrm{pH}$ regions and could be detected with absorbance at $405 \mathrm{~nm}$; with the 4-methylumbelliferyl phosphate (4MUP) substrate, the product 4-methylumbelliferone gives a large fluorescent emission intensity at $450 \mathrm{~nm}$ with excitation at $325 \mathrm{~nm}$ [26]. BIALP is applied to chemiluminescence immunoassay, too. It dephosphorylates the substrate, adamantyl 1, 2-dioxetanephenyl phosphate (AMPPD), to produce a phenoxide intermediate, which decomposes to produce light emission at $470 \mathrm{~nm}$ $[27,28]$. The detection limit for the enzyme is $1 \mathrm{zmol}\left(10^{-21} \mathrm{~mol}\right)$ and the light emission is a long-lived glow $(>1 \mathrm{~h})$. The results presented in this study that diethanolamine, triethanolamine, and $N$-methylethanolamine activated BIALP with pNPP suggest that they also activate it with 4MUP or AMPPD although the degree of activation might vary depending on substrate species.

The properties of ALP are described such as pH-activity profile [29-31], temperature-activity profile [31], thermal stability [31], and metal activation [32] by many investigations. Substitution of $\mathrm{Zn}^{2+}$ to divalent metals $\left(\mathrm{Co}^{2+}, \mathrm{Mn}^{2+}, \mathrm{Ni}^{2+}\right.$, and $\left.\mathrm{Cu}^{2+}\right)$ at catalytic site [33], and addition of these metals to reaction buffer [31] were mainstream investigations in the study of ALP activation. While a buffer constitution in the study of ALP activation was not enough to know the optimum condition for ALP reaction [17,34,35], it has suggested that ALP activity depended on reaction medium from kinetic studies of ALP $[19,20,36,37]$. Based on these lines of evidence, diethanolamine- $\mathrm{HCl}$ buffer is generally used for measurement of ALP activity [19,20,36].

In conclusion, diethanolamine, triethanolamine, and $N$-methylethanolamine highly activate BIALP and might be suitable as a dilution buffer of BIALP in EIA. Our results also 
281

282

283

284

285

286

287

288

289

290

291

292

293

294

295

296

297

298

299

300

301

302

303

304

suggest that certain additives might increase ALP activity and stability. The effects of sugars and polyalcohols on BIALP activity and stability are currently underway.

\section{References}

[1] T.W. Reid, I.B. Wilson, E. coli alkaline phosphatase, in: P.D. Boyer (Eds.), 3rd ed., The Enzymes, Vol. 4, Academic Press, New York, 1971, pp. 373-415.

[2] H.N. Fernley, Mammalian alkaline phosphatases, in: P.D. Boyer (Eds.), 3rd ed., The Enzymes, Vol. 4, Academic Press, New York, 1971, pp. 417-447.

[3] E.E. Kim, H.W. Wyckoff, Reaction mechanism of alkaline phosphatase based on crystal structures, J. Mol. Biol. 218 (1991) 449-464.

[4] T. Harada, I. Koyama, T. Matsunaga, A. Kikuno, T. Kasahara, M. Hassimoto, D.H. Alpers, T. Komoda, Characterization of structural and catalytic differences in rat intestinal alkaline phosphatase isozymes, FEBS J. 272 (2005) 2477-2486.

[5] B. Stec, K.M. Holtz, E.R. Kantrowitz, A revised mechanism for the alkaline phosphatase reaction involving three metal ions, J. Mol. Biol. 299 (2000) 1303-1311.

[6] M.M.E. de Backer, S. McSweeney, P.F. Lindley, E. Hough, Ligand-binding and metal-exchange crystallographic studies on shrimp alkaline phosphatase, Acta Cryst. D60 (2004) 1555-1561.

[7] P. Gettins, J.E. Coleman, ${ }^{31} \mathrm{P}$ nuclear magnetic resonance of phosphoenzyme intermediates of alkaline phosphatase, J. Biol. Chem. 258 (1983) 408-416.

[8] J.E Murphy, T.T. Tibbitts, E.R. Kantrowitz, Mutations at positions 153 and 328 in Escherichia coli alkaline phosphatase provide insight towards the structure and function of mammalian and yeast alkaline phosphatase, J. Mol. Biol. 253 (1995) 604-617. 
[9] M.S. Blake, K.H. Johnston, G.R. Russell-Jones, E.C. Gotschlich, A rapid, sensitive methods for detection of alkaline phosphatase-conjugated anti-antibody on Western blots, Anal. Biochem. 136 (1984) 175-179.

[10] E. Jablonski, E.W. Moomaw, R.H. Tullis, J.L. Ruth, Preparation of oligodeoxynucleotide-alkaline phosphatase conjugated and their use as hybridization probes, Nucleic Acids Res. 14 (1986) 6115-6128.

[11] D.W. Chan, Automation of immunoassays, In: Immunoassay, E.P. Diamandis, T.K.

Christopoulos (Eds), Academic Press, New York, 1996, pp. 483-504.

[12] J.P. Gosling, Immunoassay, in: E.P. Diamandis, T.K. Christopoulos (Eds), Academic Press, New York, 1996, pp. 287-308.

[13] K. Morimoto, K. Inouye, Single-step purification of $F\left(a b^{\prime}\right)_{2}$ fragments of mouse monoclonal antibodies (immunoglobulins G1) by hydrophobic interaction high performance liquid chromatography using TSKgel Phenyl-5PW, J. Biochem. Biophys. Methods 24 (1992) 107-117.

[14] K. Morimoto, K. Inouye, Single-step purification of $F\left(a b^{\prime}\right)_{2 \mu}$ fragments of mouse monoclonal antibodies (immunoglobulins M) by hydrophobic interaction high-performance liquid chromatography using TSKgel ether-5PW, J. Biochem. Biophys. Methods 26 (1993) 27-39.

[15] K. Morimoto, K. Inouye, A sensitive enzyme immunoassay of human thyroid-stimulating hormone (TSH) using bispecific $\mathrm{F}\left(\mathrm{ab}^{\prime}\right)_{2}$ fragments recognizing polymerized alkaline phosphatase and TSH, J. Immunol. Methods 205 (1997) 81-90.

[16] K. Morimoto, K. Inouye, Method for the preparation of bispecific $F\left(a b^{\prime}\right)_{2 \mu}$ fragments from mouse monoclonal antibodies of the immunoglobulin $\mathrm{M}$ class and characterization of the fragments, J. Immunol. Methods 224 (1999) 43-50. 
[17] A. Bannister, R.L. Foster, Buffer-induced activation of calf intestinal alkaline phosphate,

[18] R.A. Stinson, Kinetic parameters for the cleaved substrate, and enzyme and substrate stability, vary with the phosphoacceptor in alkaline phosphatase catalysis, Clin. Chem. 39 (1993) 2293-2297.

[19] T. Manes, M.F. Hoylaerts, R. Muller, F. Lottspeich, W. Holke, J.L. Millan, Genetic complexity, Structure, and characterization of highly active bovine intestinal alkaline phosphatases, J. Biol. Chem. 273 (1998) 23353-23360.

[20] R.A. Stinson, J.L. McPhee, H.B. Collier, Phosphotransferase activity of human alkaline phosphatase and the role of enzyme $\mathrm{Zn}^{2+}$, Biochim. Biophys. Acta 913 (1987) 272-278. [21] Z. Yang, X.J. Liu, C. Chen, P.J. Halling, Hofmeister effects on activity and stability of alkaline phosphatase, Biochim. Biophys. Acta 1084 (2010) 821-828.

[22] K. Inouye, Effects of salts on thermolysin: activation of hydrolysis and synthesis of $N$-carbobenzoxy-L-aspartyl-L-phenylalanine methyl ester, and a unique change in the absorption spectrum of thermolysin, J. Biochem. 112 (1992) 335-340.

[23] K. Inouye, S.-B. Lee, B. Tonomura, Effect of amino acid residues at the cleavable site of substrates on the remarkable activation of thermolysin by salts, Biochem. J. 315 (1996) 133-138.

[24] K. Inouye, K. Kuzuya, B. Tonomura, Effect of salts on the solubility of thermolysin: a remarkable increase in the solubility as well as the activity by the addition of salts without aggregation or dispersion of thermolysin, J. Biochem. 123 (1998) 847-852. Biol. 384 (2008) 1174-1189. 
353

354

355

356

357

358

359

360

361

362

363

364

365

366

367

368

369

370

371

372

373

374

375

376

[26] T.K. Christopoulos, E.P. Diamandis, in: Immunoassay, E.P. Diamandis, T.K. Christopoulos (Eds), Academic Press, New York, 1996, pp. 309-335.

[27] L.J. Kricka, in: Immunoassay, Edited by E. P. Diamandis and T. K. Christopoulos (Eds), Academic Press, New York, 1996, pp. 337-353.

[28] S. Sekiguchi, H. Kohno, K. Yasukawa, K, Inouye, Study on chemiluminescent enzyme immunoassay for the measurement of leptin, Biosci. Biotechnol. Biochem. in press.

[29] R.K. Morton, Some properties of alkaline phosphatase of cow's milk and calf intestinal mucosa, Biochem. J. 60 (1955) 573-582.

[30] D. Chappelet-Tordo, M. Fosset, M. Iwatsubo, C. Gache, M. Lazdunski, (1974) Intestinal alkaline phosphatase. Catalytic properties and half of the sites reactivity, Biochemistry 13 (1974) 1788-1795.

[31] H.N. Fernley, P.G. Waker, Kinetic behaviour of calf-intestinal alkaline phosphatase with 4-methylumbelliferyl phosphate, Biochem. J. 97 (1965) 95-103.

[32] D.J. Plocke, B.L. Vallee, Interaction of alkaline phosphatase of E. coli with metal ions and chelating agents, Biochemistry 1 (1962) 1039-1043

[33] M.L. Applebury, B.P. Johnson, J.E. Coleman, Phosphate binding to alkaline phosphatase. Metal ion dependence, J. Biol. Chem. 245 (1970) 4968-4976.

[34] S. Yan, L. Liu, X. Tian, Y. Zhang, H. Zhou, Effect of extraneous zinc on calf intestinal alkaline phosphatase, J. Protein Chem. 22 (2003) 371-375.

[35] T.U. Hausamen, R. Helgar, W. Rick, W. Gross, Optimal conditions for the determination of serum alkaline phosphatase by a new kinetic method, Clin. Chim. Acta 15 (1967) 241-245.

[36] R.B. McComb, G.N. Bowers Jr, Study of optimum buffer conditions for measuring alkaline phosphatase activity in human serum, Clin. Chem. 18 (1972) 97-104. 
377 [37] R. Han, J.E. Colman, Dependence of the phosphorylation of alkaline phosphatase by 378 phosphate monoesters on the $\mathrm{p} K_{\mathrm{a}}$ of the leaving group, Biochemistry 34 (1995) 4238-4245. 
380

381

382

383

384

385

386

387

388

389

390

391

392

393

394

395

396

397

398

399

400

401

402

\section{Figure legends}

Fig. 1. Molecular structures of the aminoalcohols and amines examined.

Fig. 2. Dependence of the initial reaction rate $\left(v_{0}\right)$ on the pNPP concentration in the BIALP-catalyzed hydrolysis of pNPP in the presence of diethanolamine. The reaction was carried out in $0.05(\bigcirc), 0.25(\triangle), 1.0(\square)$, and $3.0(\diamond) \mathrm{M}$ diethanolamine-HCl buffer containing $1.0 \mathrm{mM} \mathrm{MgCl} 2,20 \mu \mathrm{M} \mathrm{ZnCl}$, at $\mathrm{pH} 9.8$, at $20^{\circ} \mathrm{C}$. The initial enzyme concentration, $[\mathrm{E}]_{\mathrm{o}}$, is $40 \mathrm{pM} . v_{\mathrm{o}}$ is plotted against pNPP concentrations of $0-5.0 \mathrm{mM}(\mathrm{A})$ and 0-1.0 $\mathrm{mM}(\mathrm{B})$. Solid line represents the best fit of the Michaelis-Menten equation using the nonlinear least-squares methods.

Fig. 3. Dependence of $v_{\mathrm{o}}$ on the pNPP concentration in the BIALP-catalyzed hydrolysis of pNPP in the presence of amines and alcohols. The reaction was carried out in the presence of $1.0 \mathrm{mM} \mathrm{MgCl} l_{2}$ and $20 \mu \mathrm{M} \mathrm{ZnCl}_{2}$, at $\mathrm{pH} 9.8$, at $20^{\circ} \mathrm{C}$. [E $]_{\mathrm{o}}$ is $40-400 \mathrm{pM}$. The $v_{\mathrm{o}} /[\mathrm{E}]_{\mathrm{o}}$ is plotted against pNPP concentrations. Solid line represents the best fit of the Michaelis-Menten equation using the nonlinear least-squares methods. Symbols for the buffers: 1.0 M diethanolamine, $\bigcirc ; 1.0 \mathrm{M}$ ethylamine, $\triangle$; and $0.5 \mathrm{M}$ ethanol, ; $1.0 \mathrm{M}$ methylamine, $\square$; and 1.0 M dimethylamine, $\diamond$.

Fig. 4. Dependence of $v_{\mathrm{o}}$ on the pNPP concentration in the BIALP-catalyzed hydrolysis of pNPP in the presence of aminoalcohols. The reaction was carried out in the presence of 1.0 $\mathrm{mM} \mathrm{MgCl} l_{2}$ and $20 \mu \mathrm{M} \mathrm{ZnCl}_{2}$, at $\mathrm{pH} 9.8$, at $20^{\circ} \mathrm{C}$. [E $]_{\mathrm{o}}$ is $40-400 \mathrm{pM}$. The $v_{\mathrm{o}} /[\mathrm{E}]_{\mathrm{o}}$ is plotted 
403

404

405

406

407

408

409

410

411

412

413

414

415

416

417

418

419

420

against pNPP concentrations. Solid line represents the best fit of the Michaelis-Menten equation using the nonlinear least-squares methods. Symbols for the buffers: $1.0 \mathrm{M}$ diethanolamine, $\bigcirc ; 1.0 \mathrm{M}$ ethanolamine, $\triangle ; 1.0 \mathrm{M}$ triethanolamine, $\square ; 1.0 \mathrm{M}$ $N$-methylethanolamine, $\diamond$; and $0.5 \mathrm{M}$ borate- $\mathrm{NaOH}$.

Fig. 5. Dependence of $v_{\mathrm{o}}$ on the aminoalcohol concentration in the BIALP-catalyzed hydrolysis of pNPP in the presence of aminoalcohols. The reaction was carried out in the presence of $1.0 \mathrm{mM} \mathrm{MgCl}_{2}$ and $20 \mu \mathrm{M} \mathrm{ZnCl}_{2}$, at $\mathrm{pH} 9.8$, at $20^{\circ} \mathrm{C}$. [E $]_{\mathrm{o}}$ is $40 \mathrm{pM}$. The $v_{\mathrm{o}} /[\mathrm{E}]_{\mathrm{o}}$ is plotted against the concentrations of diethanolamine (A), triethanolamine (B), and $N$-methylethanolamine (C). Solid line represents the best fit of the Michaelis-Menten equation using the nonlinear least-squares methods. Symbols for pNPP concentration $(\mathrm{mM})$ :

(A) $0.2, \bigcirc ; 0.4, \triangle ; 0.6, \square ; 0.8, \diamond ; 1.0, \nabla ; 2.0, \bigcirc ; 3.0, \boldsymbol{\Delta} ; 4.0, \mathbf{\square}$; and 5.0,
$0.1, \bigcirc ; 0.2, \triangle ; 0.4, \square ; 0.6, \diamond ; 0.8, \nabla ; 1.0$
; 1.5
$\mathbf{\Delta} ; 2.0, \mathbf{\square} ;$ and 3.0
(C) $0.2, \bigcirc$;

$0.4, \triangle ; 0.6, \square ; 1.0, \diamond ; 1.5, \nabla ; 2.0$

; 3.0 ,

$\mathbf{\Delta} ; 4.0, \mathbf{\square}$; and 5.0, 
$\mathrm{H}_{3} \mathrm{C} \backslash \mathrm{NH}_{2}$

methylamine<smiles>CNC</smiles>

dimethylamine<smiles>CCN</smiles>
ethylamine<smiles>CCO</smiles>
ethanol<smiles>NCCO</smiles>
ethanolamine<smiles>OCCNCCO</smiles>
diethanolamine<smiles>OCCN(CCO)CCO</smiles>

triethanolamine<smiles>CNCCO</smiles>

$N$-methylethanolamine 
A

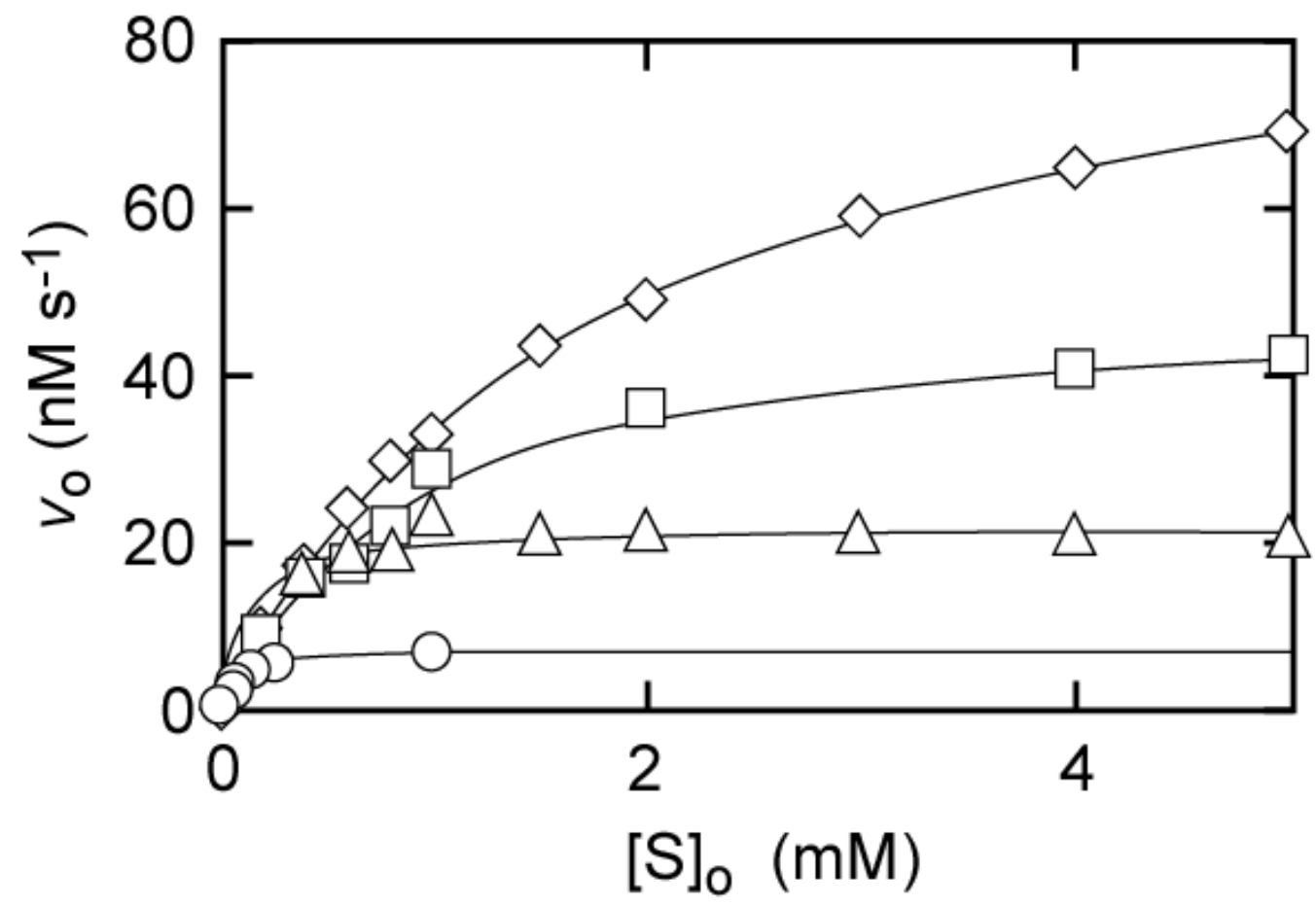

B

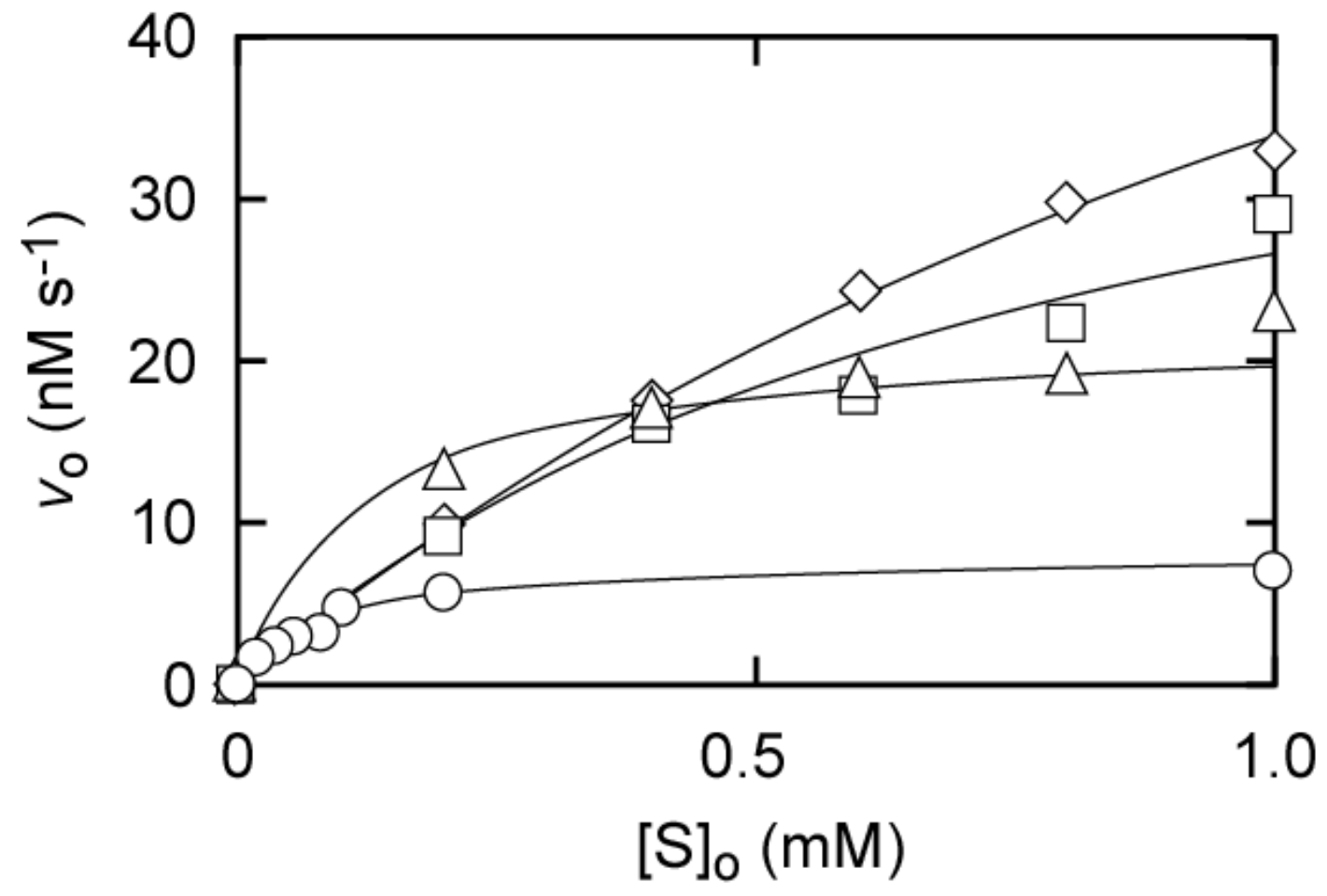

Fig. 2. Sekiguchi et al. 


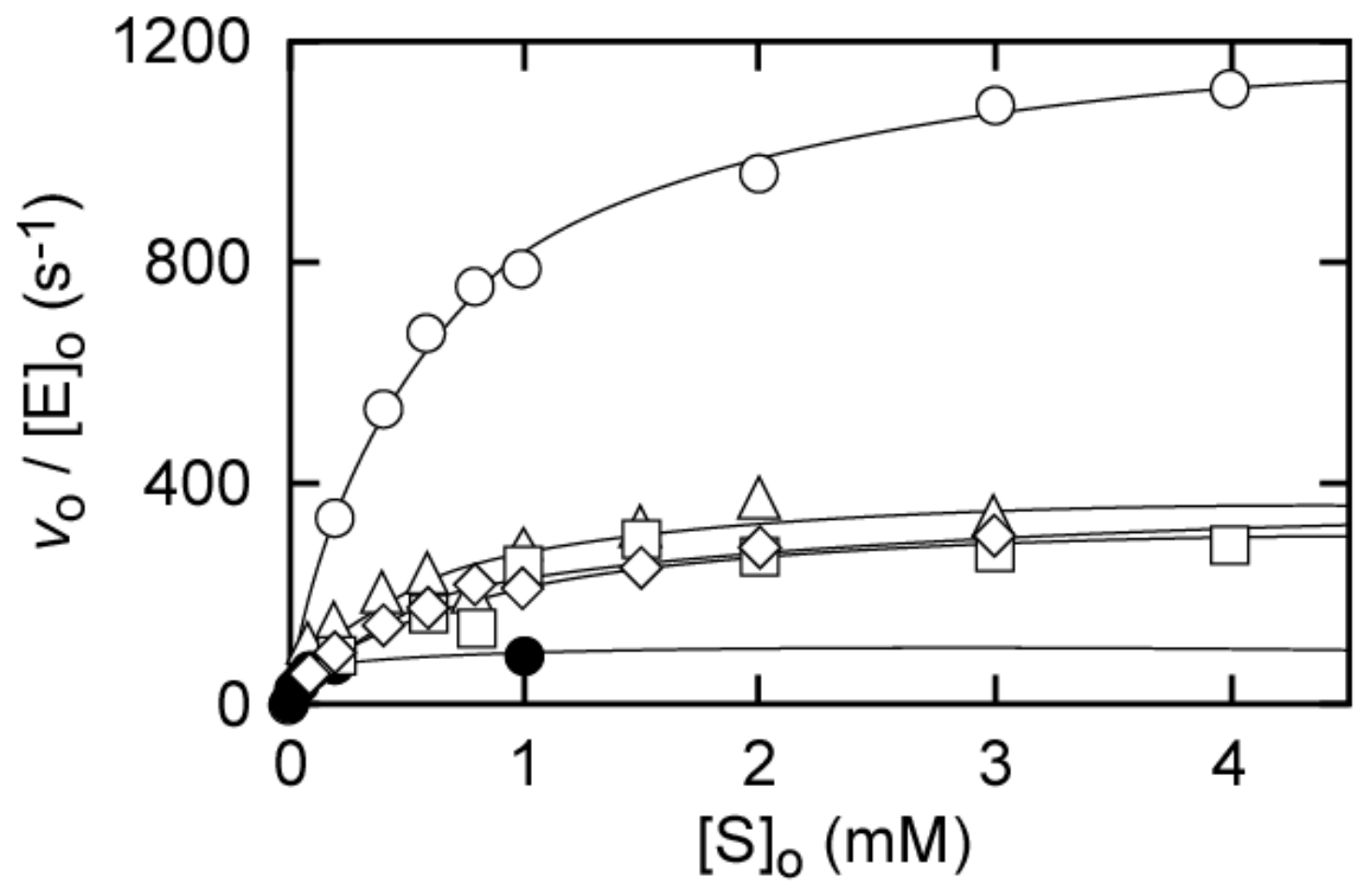

Fig. 3. Sekiguchi et al. 


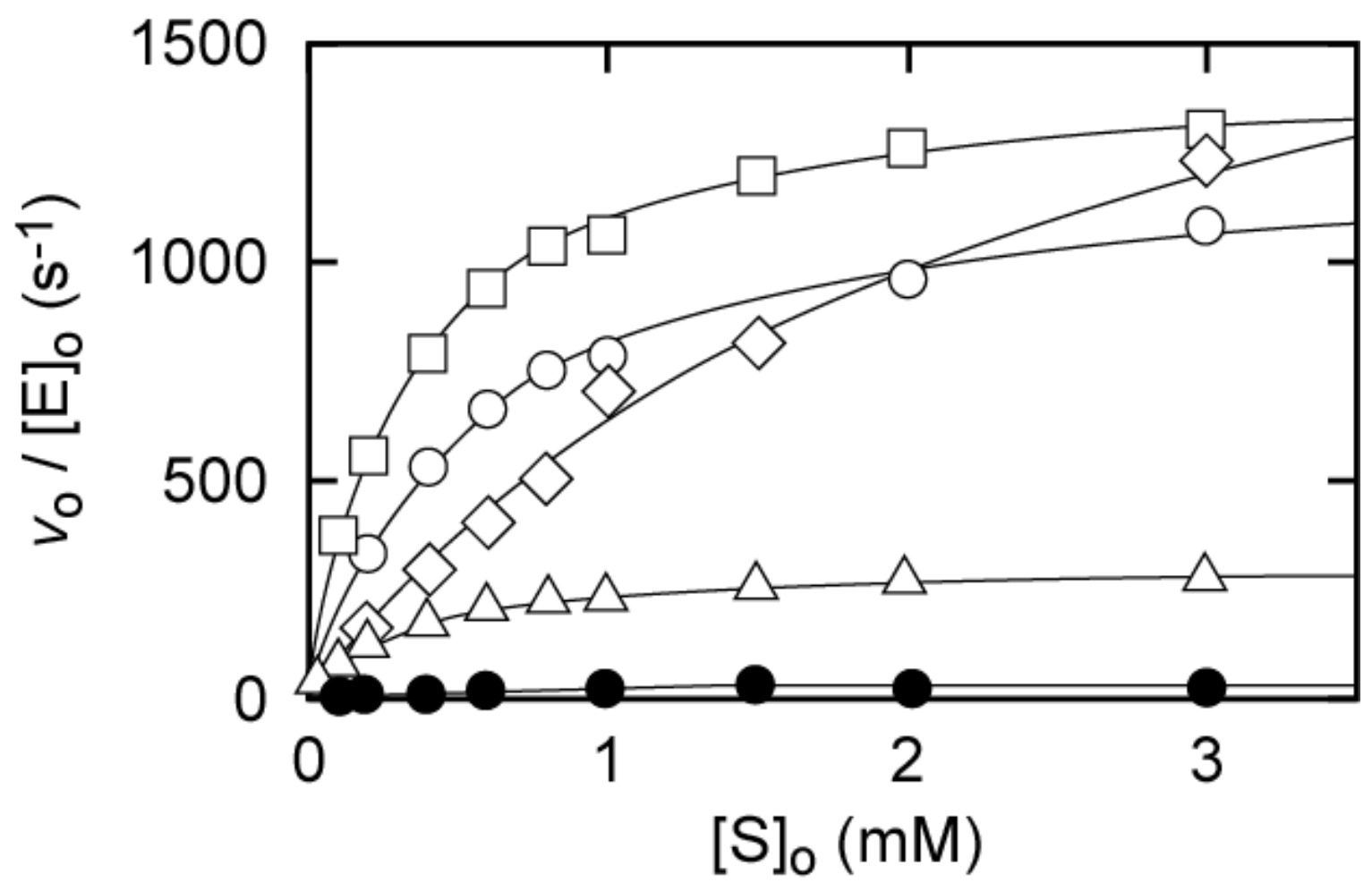

Fig. 4. Sekiguchi et al. 
A

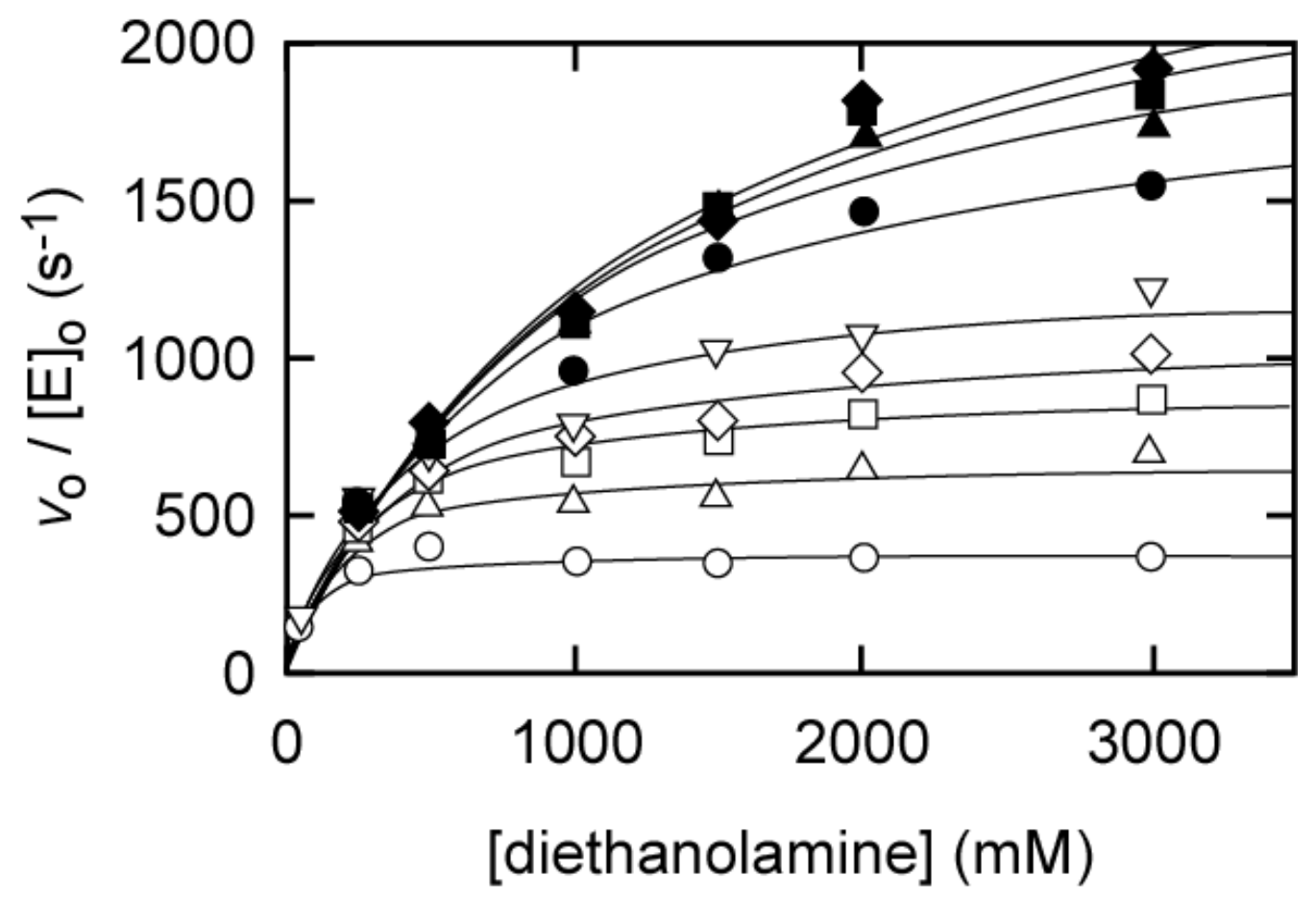

B

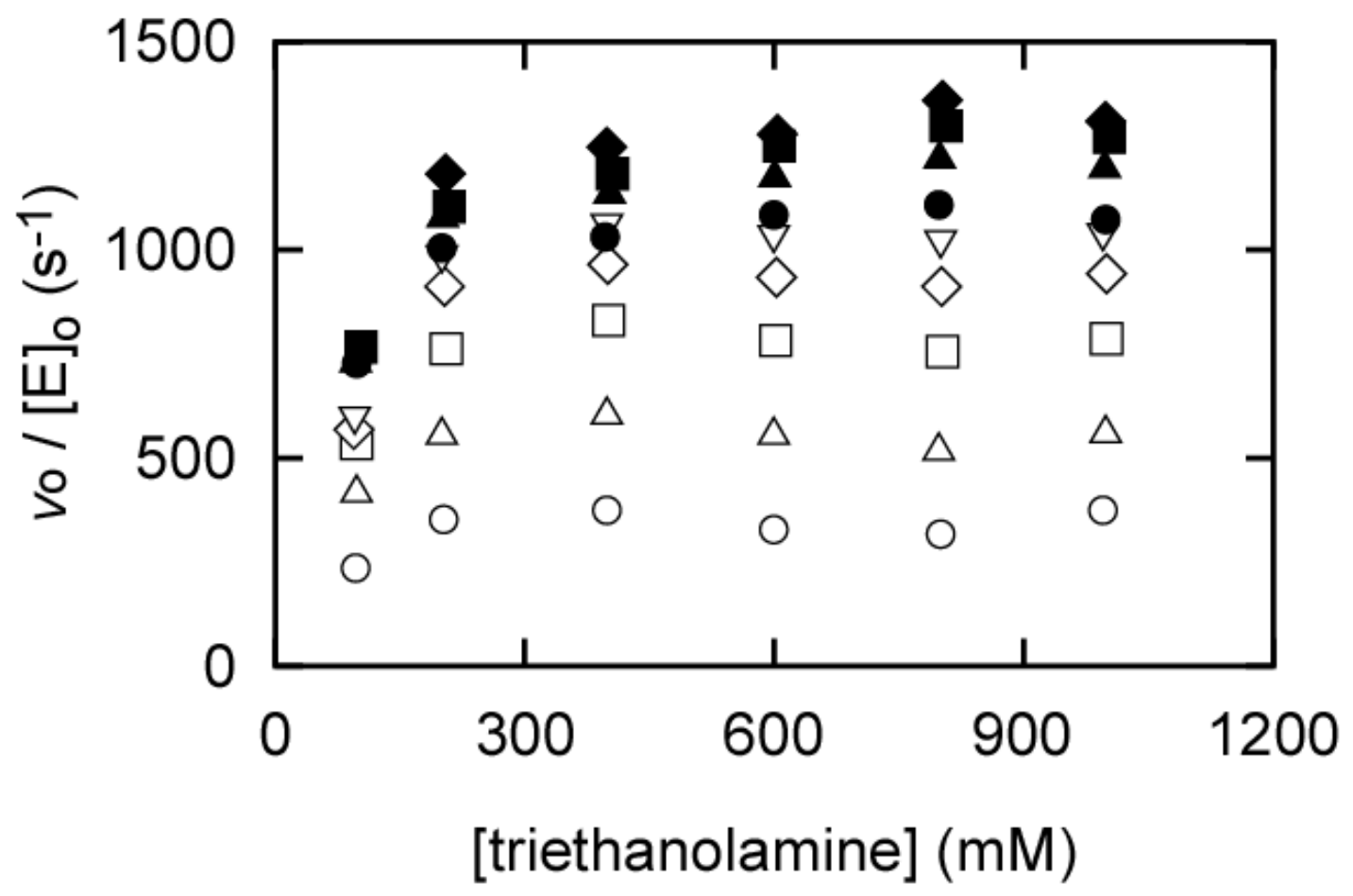

Fig. 5. Sekiguchi et al. 


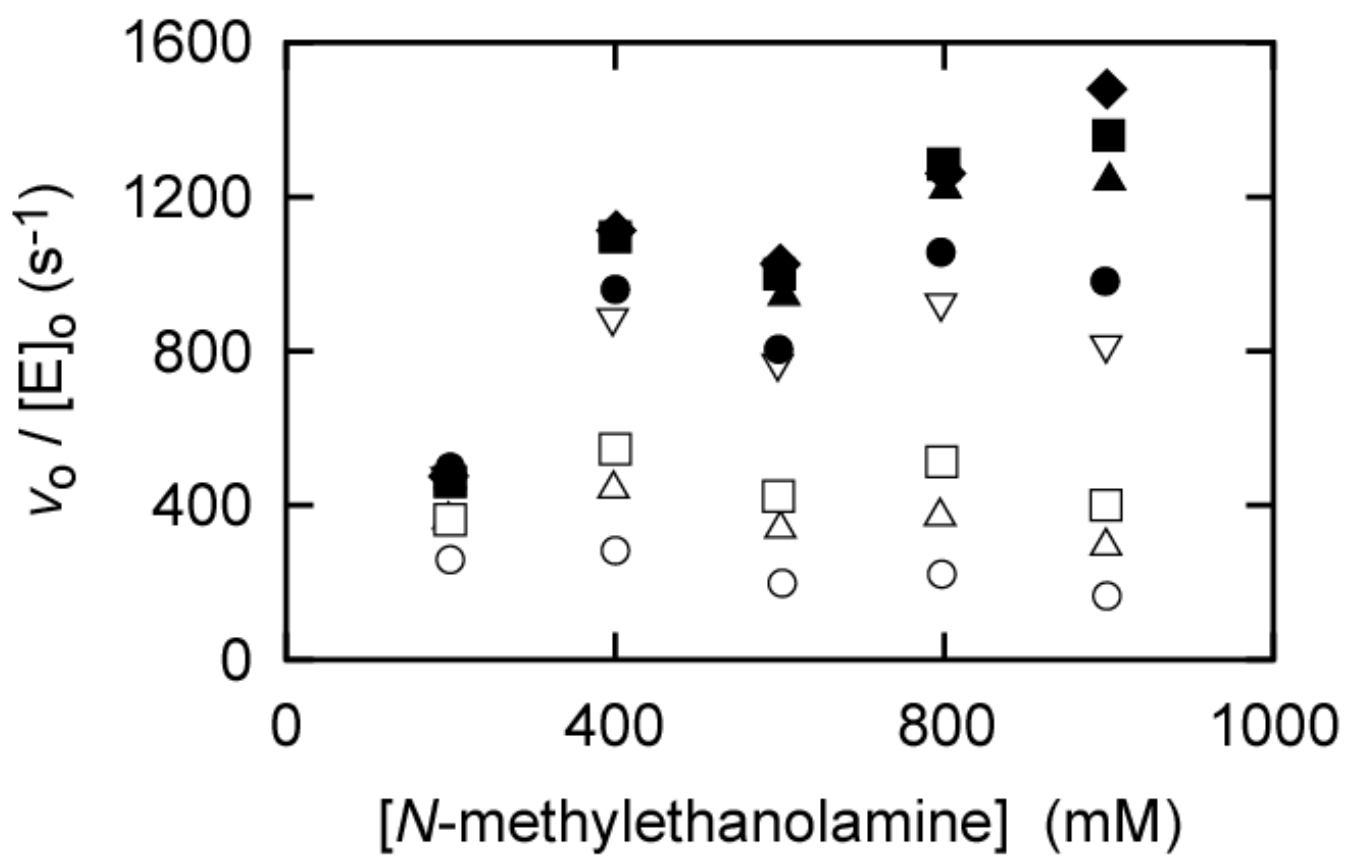

Fig. 5. Sekiguchi et al. 